\title{
Soil Microbial Functional Diversity Responds to Plant-Based Organic Fertlisers Depending on the Group of Carbon Sources
}

\author{
Monika Toleikiene ${ }^{1 *}$, Renata Zvirdauskiene ${ }^{1}$, Skaidre Suproniene ${ }^{1}$, \\ Ausra Arlauskiene ${ }^{2}$, Caroline Brophy ${ }^{3}$, Zydre Kadziuliene ${ }^{1}$ \\ ${ }^{1}$ Institute of Agriculture, Lithuanian Research Centre for Agriculture and Forestry, Akademija, Lithuania \\ ${ }^{2}$ Joniškèlis Experimental Station, Lithuanian Research Centre for Agriculture and Forestry, Joniškèlis, Lithuania \\ ${ }^{3}$ School of Computer Science and Statistics, Trinity College Dublin, Ireland
}

Received: 2 June 2020

Accepted: 7 November 2020

\begin{abstract}
The aim of the present study was to assess the influence of innovative plant-based fertilisers on soil microbial functional diversity in organically managed soil. Five fertilisers were chosen for the comparison: fresh red clover biomass (RC), fermented red clover biomass (FerRC), fermented pea and spring wheat biomass $(\mathrm{FerP}+\mathrm{W})$, composted red clover and straw biomass $(\mathrm{ComRC}+\mathrm{S})$, granulated cattle manure (GCM). Measurements of microbial functional diversity were recorded at two weeks, four months and 14 months after fertilisation. The findings of this study suggested that functional diversity of microbial communities was greater in soil fertilised with organic plant-based fertilisers than with no fertiliser treatment. Averaging across the utilisation of all 31 carbon sources, differences in average well colour developing (AWCD) across fertilised soils were not significant; however, there were significant differences in AWCD between the six different carbon substrate groups. The study also demonstrates important impacts of time: two weeks after fertlisers incorporation, microbial metabolic potential increases in complex carbon and amines substrates in RC, FerRC and GCM; four months later, the significantly greater utilisation is estimated for carbohydrates in $\mathrm{GCM}$ and $\mathrm{ComRC}+\mathrm{S}$; and the highest utilisation ratio was reached after 14 months in the amino acid substrates group in RC and GCM.
\end{abstract}

Keywords: amines, biodiversity, carbon utilization, red clover

\section{Introduction}

In the last decade, European organic farming was associated with a reduction in livestock farms and an

*e-mail: monika.toleikiene@lammc.lt

increase of plant-based farming culture. The application of plant-based organic fertilisers has been shown to be an adequate strategy for increasing the level of organic matter in soils, with benefits for the development of soil microorganisms and plants [1-3]. The heterotrophic microorganisms in the soil play a key role in the carbon cycle and humus formation by mineralizing the plant manure [4]. Shift of microbial functional 
diversity affects biogeochemical cycles in the soil and directly influence crop productivity and overall agro-ecosystem's health in short or long-term periods [5-7].

It has been shown that soil microbial community composition is sensitive to soil management type [8]. Yang et al. [9] states that soil microbial community diversity is significantly higher in soils treated with green manure. Soil microbial community structures and their diversity were found to be altered by cultivating legumes and applying fresh matter in cropping systems [10]. While many studies are in agreement about the positive effects of applying plant-based biomass, soil microbial status can be differently affected by amount and type of organic matter input [11]. It remains unclear how microbial composition and biological activity are affected in soils treated with processed plant-based organic fertilisers.

Significant increases in average well colour developing (AWCD), richness and the ShannonWeaver index may be expected by an increase in carbon availability [12], also $\mathrm{C}: \mathrm{N}$ and $\mathrm{C}: \mathrm{P}$ ratios while processing plant residues [13]. Therefore, these are the reasons for encouraging additional plant-based fertilisers preparation by composting and ensiling legume biomass to alter the $\mathrm{C}: \mathrm{N}$ ratio and to prolong the effect of fertilising throughout the crop rotation [14]. Innovative practices involve red clover (Trifolium pratense L.) and field pea (Pisum sativum) biomass processing and mixing of plants with different chemical compositions [15-16], which may positively impact soil microbial activity and bacterial functional diversity [13]. The utilisation of available carbon is the key factor governing soil microbial functional diversity [17]. The ability of microorganisms to catabolise different sources and groups of carbon can be determined by communitylevel physiological profiling (CLPP) [18].

The aim of this study was to assess the influence of plant-based organic fertilisers on soil microbial functional diversity, using processed legume biomass produced by mulching, ensiling, composting and mixing plant residues with different $\mathrm{C}: \mathrm{N}$ ratios and chemical compositions.

\section{Material and Methods}

\section{Experimental Site and Conditions}

A field experiment was conducted during the 2015-2017 crop rotation at the Lithuanian Centre for Agriculture and Forestry in Akademija $\left(55^{\circ} 24^{\prime} \mathrm{N}\right)$, Lithuania. The soil at the experimental site is loam Endocalcaric Epigleyic Cambisol (Drainic, Loamic) CM-can.glp-dr.lo. The soil plough layer was $0-25 \mathrm{~cm}$, with a humus content of $2.7 \%$, total nitrogen $1.17 \mathrm{~g} \mathrm{~kg}^{-1}$, labile phosphorus $0.51 \mathrm{~g} \mathrm{~kg}^{-1}$ and labile potassium $0.68 \mathrm{~g} \mathrm{~kg}^{-1}$. The site was managed organically since 2003. Mean annual air temperature in the experimental site during $2015-2017$ reached $7.9^{\circ} \mathrm{C}$ and was $1.3{ }^{\circ} \mathrm{C}$ higher than perennial. The average monthly precipitation in 2015 was similar to standard climate rate and reached $41 \mathrm{~mm}$ per month, but in 2016 and 2017 it was 19-21 mm per month higher than in 2015.

The experimental area was divided into 24 plots and the following crop rotation was applied to all plots: in 2015, winter wheat (Ada variety; seed rate 5.5 million $\mathrm{ha}^{-1}$ ) was sown; in 2016, spring wheat (Vanek; 6.0 million ha ${ }^{-1}$ ) was sown; and in 2017, spring barley (Noja, 5.0 million ha ${ }^{-1}$ ) plus red clover (Vyliai; 7.0 million $\mathrm{ha}^{-1}$ ) was sown. Traditional organic cultivation was used, namely stubble harvesting, deep autumn ploughing after harvesting and cultivation in the spring.

Six fertiliser treatments were established: control with no fertilisers (C), fresh red clover biomass (RC), red clover biomass fermented under anaerobic conditions (FerRC), fermented pea and spring wheat biomass $(\mathrm{FerP}+\mathrm{W})$, composted red clover and straw biomass, in a ratio of 4:1 (ComRC+S) and granulated cattle manure (GCM) for comparison. Each organic fertiliser treatment was randomly assigned to four plots arranged in a complete randomised block design and applied to plots in the spring of 2016, excluding the second treatment $(\mathrm{RC})$ which was applied in the autumn of 2015. After spreading, the fertilisers were incorporated into the $0-10 \mathrm{~cm}$ layer of the soil.

\section{Chemical Analysis}

Before application to the plots in 2016 spring, the processed plant-based manures were analysed for chemical composition (Table 1). The chemical composition of plant material was determined by the following methods: $\mathrm{C}_{\text {tot }}\left(\mathrm{g} \mathrm{kg}^{-1}\right)-$ Diameter method (automatic Vario EL Analyzer); $\mathrm{N}_{\text {tot }}\left(\mathrm{g} \mathrm{kg}^{-1}\right)-$ Kjeldahl method using a final photometric determination (UV/Vis Cary 50 Conc); $\mathrm{P}_{\text {tot }}\left(\mathrm{g} \mathrm{kg}^{-1}\right)$ - final photometric determination (UV/Vis Cary 50 Conc); and $\mathrm{K}_{\text {tot }}\left(\mathrm{g} \mathrm{kg}^{-1}\right)$ - atomic absorption method (ANALYST 200 atomic absorption spectrophotometer).

\section{Community-Level Physiological Profiling}

Changes in the activity of soil microorganisms were assessed at three time points: two weeks after fertiliser (plant-based manure) application (17 May 2016); after harvesting - approximately four months after fertiliser application, (31 August 2016); and 14 months after fertiliser application, during vegetative growth of spring barley with clover (18 July 2017). Soil samples were collected from the $0-10 \mathrm{~cm}$ soil layer for laboratory analysis, with four replicates for each treatment. Five samples of soil were taken from each plot and mixed.

Biolog Ecoplates (BIOLOG Inc, Hayward, CA, USA) containing 31 different carbon sources, plus a water control have been used. According to Garland 
Table 1. Chemical composition and C:N ratio of plant-based organic manures before application to the plots.

\begin{tabular}{|c|c|c|c|c|c|}
\hline \multirow{2}{*}{$\begin{array}{c}\text { Organic plant-based } \\
\text { fertilisers }\end{array}$} & \multicolumn{5}{|c|}{ Chemical compounds, $\mathrm{g} \mathrm{kg}^{-1} \mathrm{DM}$} \\
\cline { 2 - 6 } & $\mathrm{C}_{\mathrm{tot}}$ & $\mathrm{N}_{\text {tot }}$ & $\mathrm{P}_{\text {tot }}$ & $\mathrm{K}_{\text {tot }}$ & $\mathrm{C}: \mathrm{N}$ \\
\hline $\mathrm{RC}$ & 520 & 33.4 & 2.6 & 28.6 & 17.2 \\
\hline FerRC & 392 & 19.0 & 1.9 & 9.9 & $21: 1$ \\
\hline FerP+W & 378 & 10.8 & 1.8 & 30.1 & $35: 1$ \\
\hline ComRC+S & 514 & 31.4 & 6.8 & 45.2 & $16: 1$ \\
\hline GCM & 469 & 27.6 & 5.8 & $17: 1$ \\
\hline
\end{tabular}

Abbreviations: RC - fresh red clover biomass; FerRC - fermented red clover biomass; FerP $+\mathrm{W}$ - fermented pea and spring wheat biomass; ComRC $+\mathrm{S}$ - composted red clover and straw biomass; GCM - granulated cattle manure.

and Mills [18], recovery of bacterial communities involved suspending $10 \mathrm{~g}$ of dry soil samples in $90 \mathrm{ml}$ sterile $0.85 \% \mathrm{NaCl}$ solution. The soil was agitated in suspension for up to 1 hour in an orbital shaker and then left to stand for 30 minutes. The dilutions (ratio 1:100) were made to inoculate Ecoplates (Biolog Inc., Hayward, CA) with $100 \mu \mathrm{l}$ in each well. Colour development (optical density - OD) was determined by reading absorbance every 24 hours using a Microstation (MicroLog MSystem, Biolog Inc.) at a wavelength of $590 \mathrm{~nm}$ for 4 days. The data were collected using Microlog Data Collection Software 1.2 (Biolog Inc.).

\section{Calculations and Data Analysis}

Plate readings after 48 hours of incubation were used to calculate AWCD, microbial Richness (R) and Shannon diversity index $(\mathrm{H})$. After subtracting the absorbance of the control well for each substrate and setting all negative readings to zero to normalise data. AWCD values were determined according to the formula: $\mathrm{AWCD}=\Sigma(\mathrm{C}-\mathrm{S}) / 31$, where $\mathrm{C}$ is scale value of the control well (without a carbon source) and $\mathrm{S}$ is scale value of the sole carbon source of each of the 31 sources [18]. $\mathrm{R}$ values were calculated as the number of utilised carbon substrates with $\mathrm{OD}>0.25$. H was calculated according to the formula: $\mathrm{H}=-\Sigma \mathrm{pi}(\ln \mathrm{pi})$, where pi is the relative value between the absorption value and the sum of all positive wells. AWCD, R, and $\mathrm{H}$ were analysed by one-way analysis of variance (ANOVA) and mean comparisons between treatments were performed using Tukey's mean separation test. Analysis were performed using SAS software version 9.4 (SAS Institute Inc., Copyright (C) 2002-2010). The smallest significant difference R05 was calculated using a probability level of $\mathrm{P}<0.05$. Where required, repeated measures analysis was used to test for changing effects over time. Carbon substrates were divided into six groups according to Chazarenc et al. [7] (Table 2). The normalised (subtracting the control well value and negative values set to zero) OD readings of each series were averaged.

Table 2. Carbon substrates in Biolog Ecoplate wells and different carbon substrate groups.

\begin{tabular}{|c|c|c|}
\hline 0 - Water & B. Complex carbon sources & D. Phosphate-carbon \\
\hline & B1. Tween 40 & D1. Glucose-1-phosphate \\
\hline A. Carboxylic acids & B2. Tween 80 & D2. D,l- $\alpha$-glycerol phosphate \\
\hline A1. Pyruvic acid methyl ester & B3. $\alpha$-cyclodextrin & E. Amino acids \\
\hline A2. D-glucosamic acid & B4. Glycogen & E1. L-arginine \\
\hline A3. D-galactonic acid $\gamma$-lactone & C. Carbohydrates -asparagine \\
\hline A4. D-galacturonic acid & C1. D-cellobiose & E3. I-phenylalanine \\
\hline A5. 2 -hydroxy benzoic acid & C2. $\alpha$-D-lactose & E4. L-serine \\
\hline A6. 4 -hydroxy benzoic acid & C3. $\beta$-methyl-D-glucoside & E6. Glycyl-L-glutamic acid \\
\hline A7. $\gamma$-hydroxy butyric acid & C4. D-xylose & F. Amines \\
\hline A8. Itaconic acid & C5. i-erythritol & F1. Phenylethyl amine \\
\hline A9. $\alpha$-ketobutyric acid & C6. D-mannitol & F2. Putrescine \\
\hline A10. D-malic acid & C7. N-acetyl-D-glucosamine & \\
\hline
\end{tabular}




\section{Results and Discussion}

\section{Microbial Functional Diversity Indices}

Rates of AWCD increased over time $(\mathrm{p}<0.001)$ with average values of 0.23 (2 weeks, $\mathrm{SE}=0.0126$ ), 0.35 (4 months, $\mathrm{SE}=0.0179)$ and 0.65 (14 months,

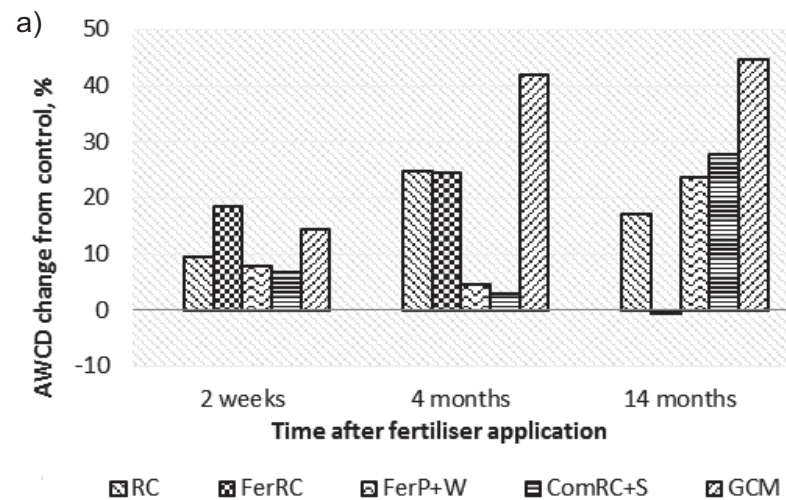

b)

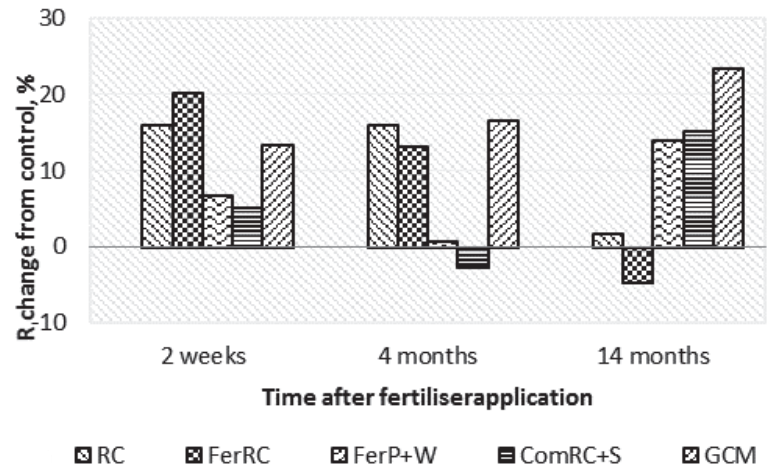

c)

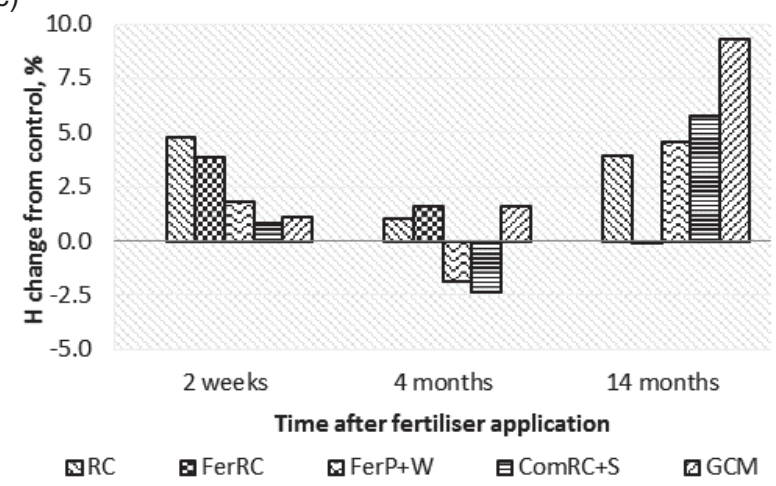

Fig. 1. Influence of the organic fertilisers on changes in soil microbial functional diversity compared to control (unfertilised) soil (\%) as indicated by: a) Average well colour development (AWCD), b) Richness (R) and c) Shannon-Weaver (H) index, at 2 weeks, 4 months and 14 months after manure application. Abbreviations: RC - fresh red clover biomass; FerRC fermented red clover biomass; FerP $+\mathrm{W}-$ fermented pea and spring wheat biomass; ComRC $+\mathrm{S}-$ composted red clover and straw biomass; GCM - granulated cattle manure, $p$ - the level of significance, $\mathrm{LSD}_{05}$ - least significant difference, than $\mathrm{p} \leq 0.05$.
$\mathrm{SE}=0.0331)$. Organic fertiliser application did not change AWCD significantly $(p=0.077)$, although some tendencies were observed. In first vegetation season, with FerRC, RC and GCM there were higher levels of AWCD. FerP $+W$ and ComRC $+\mathrm{S}$ did not produce an effect in the first year (two weeks and four months after fertilisation) but resulted in a higher AWCD level in the second year (Fig 1a). In addition, GCM produced a comparable increase in AWCD in the second year. In the third time period, GCM scores were highest (relative to the control) for AWCD, H and R (Fig. 1a, lb and 1c). Within each time period, values of AWCD were strongly correlated with rates of $\mathrm{R}$ and $\mathrm{H}$. These indices changed significantly with time, reflecting seasonal changes and different meteorological conditions, but in most cases, the plant-based organic fertilisers that were applied did not affect $\mathrm{AWCD}, \mathrm{H}$, or R values significantly. The only differences occurred when comparing organic fertiliser treatments with the control.

These results show low sensitivity of soil microbial function to different organic amendment types. Cesarano et al. [19] found that legume residues resulted in higher taxonomic microbial diversity (rRNA) when compost manure, but functional diversity (AWCD) reflects nonsignificant differences between them. Also, the microbial biomass is observed to be greater in sites where red clover had been applied [13, 20]. However, soil microbial functional diversity (AWCD) was not altered significantly with growing microbial biomass in treatments with red clover residues [13]. In the same time, mineral fertilisation is shown to differ significantly from organic manure, giving idea, that organic vs. conventional management effects microbial functional diversity stronger than type of organic matter [19].

\section{Functional Diversity According to Carbon Groups}

Since plant-based organic fertilisers have different $\mathrm{C}: \mathrm{N}$ ratios with different types of organic compounds, we investigated differences in catabolism of the carbon sources, used in Ecoplates, divided in groups (Table 1). Total absorbance values varied significantly between the five groups and significantly increased in all groups in the 14-month treatment period. During the first year (first two time periods: after two weeks and after four months) substrate consumption began to differ significantly, and microbial metabolic potential increased mostly with complex carbon sources and with amine substrates. Two weeks after manure incorporation, amine utilisation dominated with RC and FerRC, and complex carbon sources with GCM (Fig. 2a). For ComRC+S, complex carbon sources dominated after four months (Fig. 2b). There was a significantly greater difference in the utilisation of carbohydrates (GCM after 4 months in Fig. 2b); and ComRC+S after 14 months in Fig. 2c). The peak in microbial metabolic potential was reached with amino 
acid substrates (RC and GCM after 14 months in Fig. 2c).

Significantly different catabolism of the groups of carbon sources could be explained by the ability of different forms of organic fertilisers to stimulate structurally different microbial communities [8]. So differentiation of carbon substrates gives a broader and deeper perception of microbial functional diversity in soil amended with green manures. In our study, two carbon sources groups, amines and amino acids, most significantly contributed to microbial metabolic potential. Results of other research are consistent with the view that soil microbes which are responsible for nitrogen cycles are strongly affected by the plant species
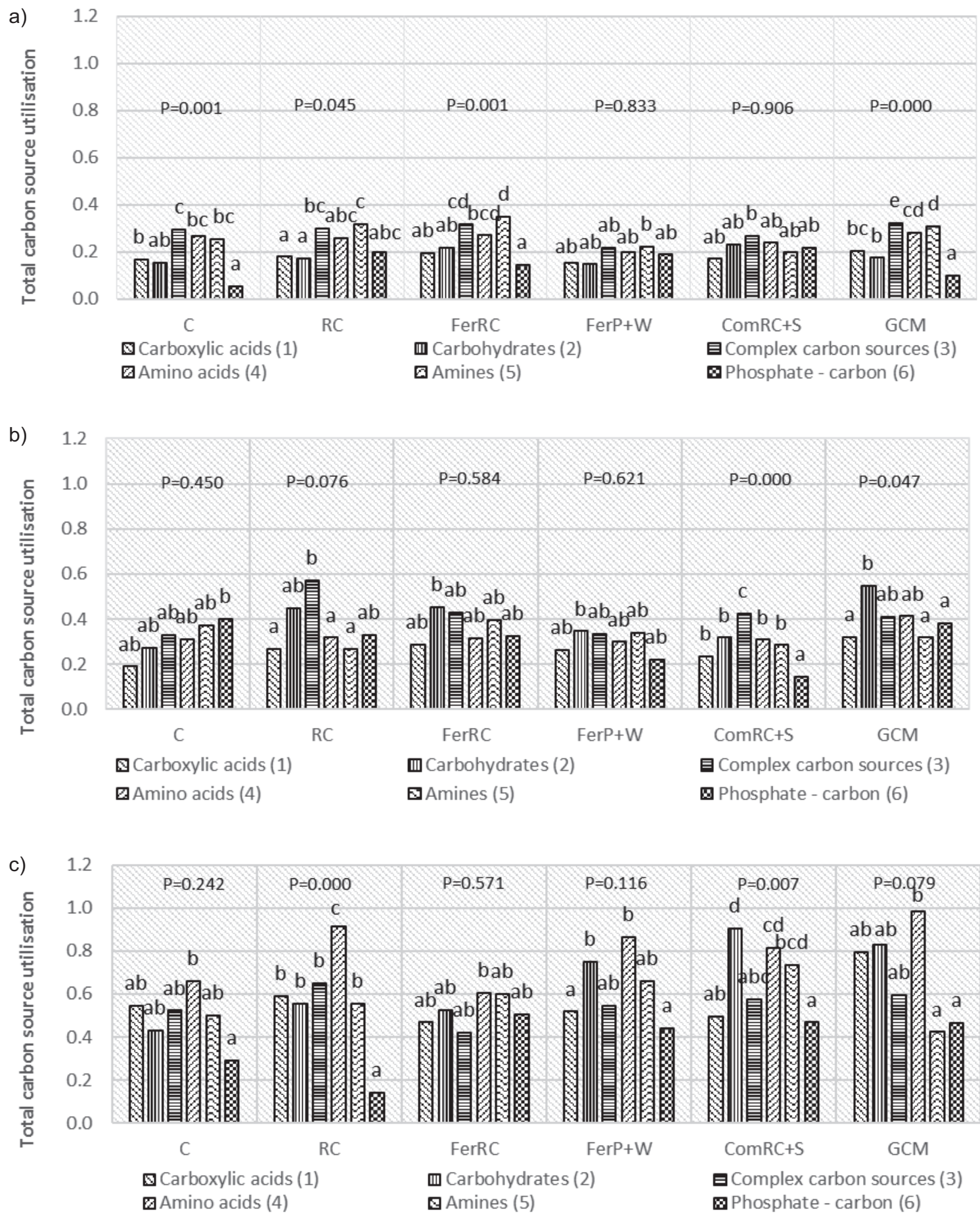

Fig. 2. Carbon sources utilisation ratio according to the total absorbance value of each carbon source group. a) 2 weeks, b) 4 months and c) 14 months after fertiliser application.

Abbreviations: $\mathrm{C}$ - control with no fertiliser; $\mathrm{RC}-$ fresh red clover biomass; FerRC - fermented red clover biomass; FerP $+\mathrm{W}-$ fermented pea and spring wheat biomass; ComRC+S - composted red clover and straw biomass; GCM - granulated cattle manure; $\mathrm{p}$ - the level of significance; abc - columns (groups of carbon) followed by the same letters in the same section do not differ one another ( $\mathrm{p} \leq 0.05)$ 
used for green manure [21]. Kato et al. [22] state that fermentation of material with a high nitrogen content could increase the proportion of soluble nitrogen and also degradability of the material. This makes the nitrogen and other nutrients in the fermented materials more available for microorganisms.

In our study, compost significantly alters microbial functional diversity later and differently compared with other fertilisers. The compost determines changes in soil microbial community, modifying its metabolic characteristics and also resulting in a different utilisation of carbon sources [23]. The microbial community of the treated soil was better able to metabolise complex substrates, such as carboxylic acids, carbohydrates and phenolic compounds, compared to control soil. Prolonged changes in microbial structures of compost treatment found due to generalist enzymes, such as proteases, lipases and esterases, $\beta$-glucosidase and dehydrogenase [24].

\section{Time Course of Fertiliser Impact}

Microbial communities from differently fertilised soils were able to use all 31 carbon sources. The lowest AWCD values were observed 2 weeks after fertiliser application; only 4 substrates reached consumption levels of more than 0.5 (Fig. 3). In the early stages, bacteria degrade only more labile substrates [25]. The microbial metabolic potential increased 4 months after fertiliser application and already 10 substrates had greater consumption by microorganisms. After 14 months, a total of $48 \%$ of the carbon substrates showed an utilisation value greater than 0.5 . The highest utilisation rates were reached with the D-galacturonic acid, L-asparagine and D-mannitol (1.630-2.044). In most studies of legume effects on soil microorganisms, soil microbial response is determined in only one season or part of a season and the soil microbial responses over the normal crop rotation are often not evaluated [26]. Scotti et al. [23] and Yang et al. [27] did not find an effect on AWCD one year after compost addition. Our study showed that a one-year experiment can miss a lot of information and functional diversity of soil microbes may have different responses to fertiliser addition depending on the duration of experiment.

Therefore, 29\% of carbon substrates showed 'I type' utilisation progress in time, where the highest grow of OD value was noticed in the period from 4 to 14 months after plant-based manure application (Fig. 3a). $42 \%$ of carbon substrates showed 'II type' utilisation progress in time, where OD values grew constantly across the three time periods (Fig. 3b). $29 \%$ of carbon substrates showed 'III type' utilisation progress in time, succeeding only small OD values with

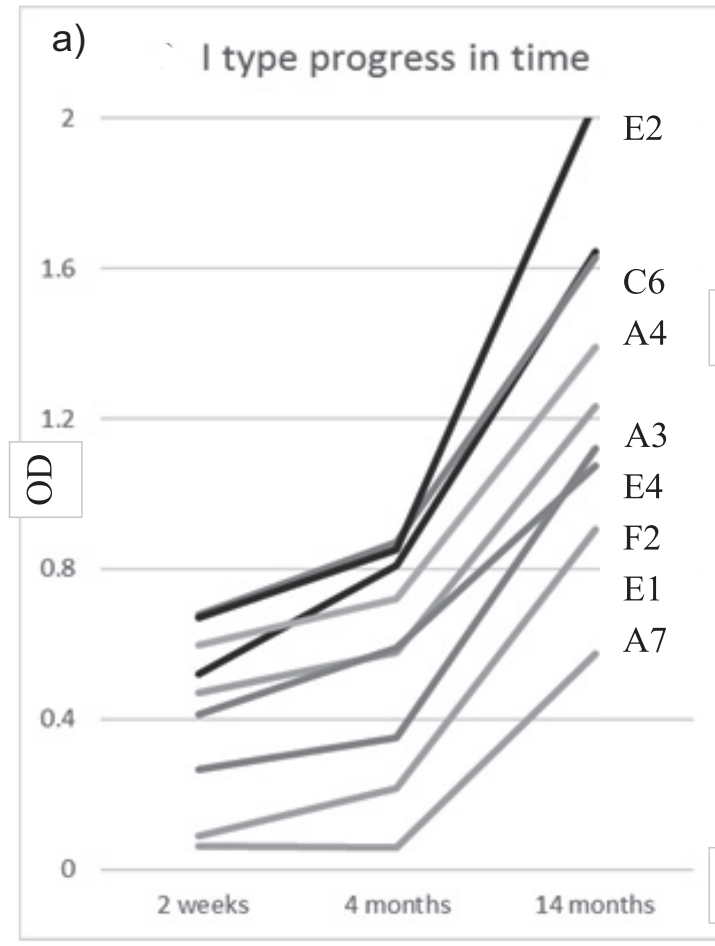

b)

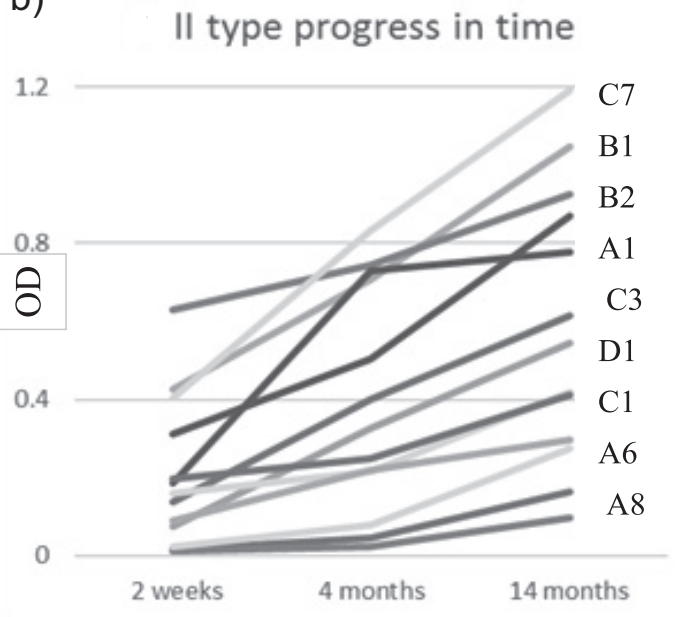

c)

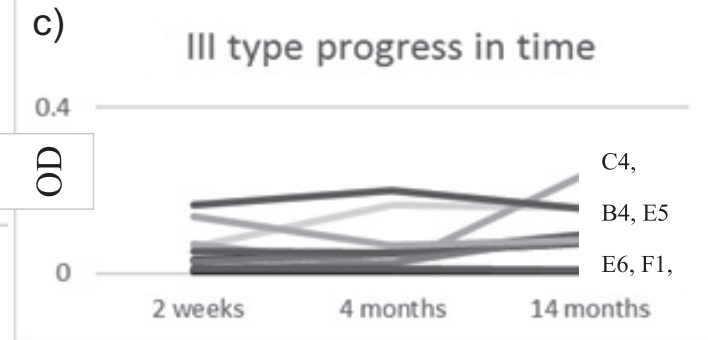

Time after fertiliser incorporation in the soil

Fig. 3. Carbon sources utilisation ratio according to the absorbance value (OD) of each 31 carbon sources, devided in III types (a, b, c) according to utilisation trends in time periods of 2 weeks, 4 months and 14 months.

Abbreviations: Capital letters A-F indicates the group of carbon sources, numbers 1-10 indicates carbon substrate in the group, as shown in Table 2. 
no clear growing tendency across the three time periods (Fig. 3c). Pascault et al. [28] found that colonisation by bacteria depends on the initial biochemical quality of the residues. Opheusden et al. [29] suggests that degradation timing is delayed for structural carbohydrates, such as cellulose, hemicellulose and lignin.
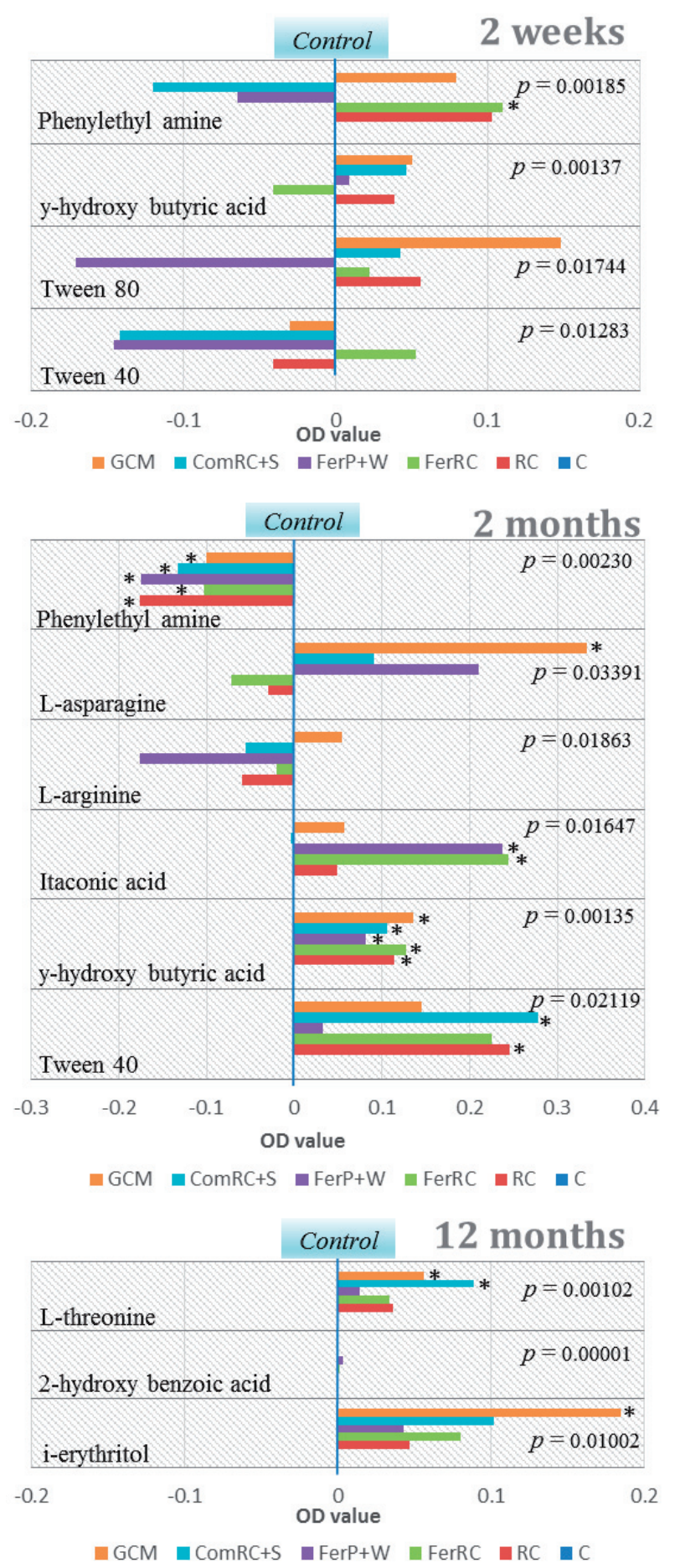

Fig. 4. The total absorbance value of carbon sources differing significantly in 6 fertilisation treatments in 3 periods after fertilisation. Abbreviations: $p$ - the level of significance; abc - significant differences between treatments, $*$ - significant differences from the control.

\section{Principal Substrates Utilisation}

Different utilisation of 4 carbon sources (phenylethyl amine, y-hydroxy butyric acid, tween 80 and tween 40) in different fertilisation treatments was observed as early as 2 weeks after fertilisation. The significantly higher utilisation of phenylethyl amine by microorganisms comparing with control (unfertilised) was reached in FerRC treatment. This means, that microorganism species, which use such amines, were promoted by additional legume biomass fermentation. The earlier peak of microbial activity, caused by higher availability of carbon sources in the fermented red clover treatment compared with the other processed forms of green manure, resulted in faster growth and quick response of microorganisms to fermented material addition [30]. Likewise, Gomez et al. [12] explained the increase in microbial community functional potential by an increase in carbon availability.

4 months after fertilisation, significant differences between treatments were found for OD values of phenylethyl amine, L-asparagine, Itaconic acid, y-hydroxy butyric acid and tween 40. Comparing with control, all treatments had significantly lower utilisation of phenylethyl amine, but significantly higher utilisation of y-hydroxy butyric acid. Apparent depression of amines and amino acids utilising organisms in treatments with legume biomass addition could be explained by the priming effect of r-strategist microorganisms in the soil [31]. The r-strategist microorganisms use easily available most energetic carbon sources and distinguishe with a short life span [32]. Only the GCM significantly promoted OD values of L-asparagine subjected to amino acids group. The fermentation of legume biomass (FerRC and FerP+W) promoted OD values of Itaconic acid, comparing with control. Itaconic acid is a polymer obtained from lignocellulose biomass through fermentation with fungi like Aspergillus terreus and Ustilago maydis [33], wherefore addition of fermented material increases the amount of itaconic acid mineralising bacteria in the soil. Since carboxylic acids like itatonic acid are not easily metabolised and can rapidly be adsorbed by soil minerals, this function of fermented legume mass is likely to improve the functional diversity of soil microorganisms.

14 months after fertilisation, significant differences between treatments were found for OD values of L-threonine, 2-hydroxy benzoic acid and i-erythritol; with $\mathrm{GCM}$ and ComRC+S having the most promoting impact comparing with control. Additional legume biomass preparation by composting changes the $\mathrm{C}: \mathrm{N}$ ratio and mineralisation (Carter et al., 2013). Therefore organic manure with high levels of mineralisation caused a significant effect in the first year, and fertilisers with medium (GCM) or low $(\mathrm{ComRC}+\mathrm{S})$ mineralisation levels promote specific carbon sources utilising microorganisms later on, with effects for up to $4-5$ years $[14,34]$. 


\section{Conclusions}

Significant differences were observed in functional microbial diversity in the soil while analyzing the microbial catabolism of different groups of applied carbon sources. Microbial catabolic potential demonstrated significant changes in time. Two weeks after organic fertiliser incorporation, amine utilisation dominated using red clover fertilisers ( $\mathrm{RC}$ and FerRC); and complex carbon sources utilisation dominated using fertiliser with higher $\mathrm{C}: \mathrm{N}$ ratio (in GCM after 2 weeks, in ComRC+S after 4 months), and later of harder degradable carbohydrates (in GCM after 4 months, in ComRC+S after 14 months). Delayed effect was observed for $\mathrm{ComRC}+\mathrm{S}$. The peak in microbial metabolic potential was reached 14 months after fertilization and the highest value for substrate utilisation involved three substrates: D-galacturonic acid, L-asparagine and D-mannitol.

Whilst the organic plant-based fertilisers positively affected microbes from different functional groups, none of them exceeded the AWCD values of granulated cattle manure.

\section{Acknowledgements}

This research was carried out as part of the research and development program of the Lithuanian Research Centre for Agriculture and Forestry and supported by the LegValue project in EU Horizon 2020 program No. 727672 .

\section{Conflict of Interest}

The authors declare no conflict of interest.

\section{References}

1. ARLAUSKIENE A., NEMEIKSIENE D., SLEPETIENE A. Innovative green manure technologies on organic farming. Eng. Rural Dev. 12, 170, 2013.

2. BASTIDA F., SELEVSEK N., TORRES I.F., HERNANDEZ T., GARCIA C. Soil restoration with organic amendments: linking cellular functionality and ecosystem processes. Sci. Rep. 5, 1, 2015.

3. NKOA K. Agricultural benefits and environmental risks of soil fertilization with anaerobic digestates: a review. Agron. Sustain. Dev. 34, 473, 2014.

4. MEYER O. Functional groups of microorganisms. In Schulze ED, Mooney HA (ed), Biodiversity and ecosystem function. Springer-Verlag, Berlin, Germany, 1994.

5. ADAMS T., BRYE K.R., SAVIN M.C., LEE J.A., GBUR E.E. Microbial carbon substrate utilization differences among high- and average-yield soybean areas. Agriculture. 7, 1, 2017.

6. NEMERGUT D.R., SCHMIDT S.K., SEAN T.F., O'NEILL P., BILINSKI T.M., STANISH L.F., KNELMAN J.E., DARCY J.L., LYNCH R.C., WICKEY P., FERRENBERG
S. Patterns and processes of microbial community assembly. Microbiol. Mol. Biol. R. 77, 342, 2013.

7. CHAZARENC F., BRISSON J., MERLIN G. Seasonal and Spatial Changes of Microorganism Communities in Constructed Wetlands: A Community Level Physiological Profiling Analysis. Int. J. Chem. Eng. 1, 2010.

8. LUNDQUIST E.J., JACKSON L.E., SCOW K.M., HSU C. Changes in microbial biomass and community composition, and soil carbon and nitrogen pools after incorporation of rye into three California agricultural soils. Soil Biol. Biochem. 31 221, 1999.

9. YANG H., NIU J., TAO J., GU Y., ZHANG C., SHE S., CHEN W., YANG H., YIN H. The impacts of different green manure on soil microbial communities and crop health. Preprints. Avalaible at: https://doi. org/10.20944/ preprints201609.0056.v1; accessed 9/11/2017. 2016.

10. TODA M., UCHIDA Y. Long-term use of green manure legume and chemical fertiliser affect soil bacterial community structures but not the rate of soil nitrate decrease when excess carbon and nitrogen are applied. Soil Res. 55, 524, 2017.

11. SHANNON D., SEN A.M., JOHNSON D.B. A comparative study of microbiology of soils managed under organic and conventional regimes. Soil Use Manage. 18, 274, 2002.

12. GOMEZ E., FERRERAS L., TORESANI S. Soil bacterial functional diversity as influenced by organic amendment application. Bioresour. Technol. 97, 1484, 2006.

13. LUPWAYI N.Z., CLAYTON G.W., O'DONOVAN J.T., HARKER K.N., TURKINGTON T.K., RICE W.A. Soil microbial properties during decomposition of crop residues under conventional and zero tillage. Can. J. Soil Sci. 84, 411, 2004

14. CARTER M.S., SØRENSEN P., PETERSEN S.O., MA X., AMBUS P. Effects of green manure storage and incorporation methods on nitrogen release and $\mathrm{N}_{2} \mathrm{O}$ emissions after soil application. Biol. Fertil. Soils. 50 1233, 2014.

15. ARLAUSKIENE A., MAIKSTENIENE S., SLEPETIENE A. The effect of catch crops and straw on spring barley nitrogen nutrition and soil humus composition. Zemdirbyste-Agriculture. 96, 53, 2009.

16. SARUNAITE L., KADZIULIENE Z., KADZIULIS L. The effect of legumes on the accumulation of nitrogen in herbage yield on succeeding spring wheat. Grassl. Sci. Europe. 11, 387, 2006.

17. MALIK A., GROHMANN E., ALVES M. Management of Microbial Resources in the Environment: A Broad Perspective. Springer, Dordrecht. ISBN 978-94-007-5930-5, 1, 2013.

18. GARLAND J.L., MILLS A.L. Classification and characterisation of heterotrophic microbial communities on the basis of pattern of community-level sole-carbonsource utilization. Appl. Environ. Microbiol. 57, 2351, 1991.

19. CESARANO G., DE FILIPPIS F., LA STORIA A., SCALA F., BANANOMI G. Organic amendment type and application frequency affect crop yields, soil fertility and microbiome composition. Appl. Soil Ecol. 120, 254, 2017.

20. TEJADA M., GONZALEZ J.L., GARCÍA-MARTÍNEZ A.M., PARRADO J. Application of a green manure and green manure composted with beet vinasse on soil restoration: Effects on soil properties. Bioresour. Technol. 99, 4949, 2008.

21. MAO Y., YANNARELL A.C., MACKIE R.I. Changes in $\mathrm{N}$-transforming archaea and bacteria in soil during the 
establishment of bioenergy crops. PLoS ONE 6: e24750. Avalaible at: doi:10.1371/journal.pone.0024750; accessed 13/3/2018. 2011.

22. KATO H., BAREEBA F.B., SABIITI E.N. Productivity of soil fertilised with fermented Calliandra, Gliricidia and Leucaena browses and maize forage. J. Agr. Sci. Technol. B. 3, 199, 2013.

23. SCOTTI R., PANE C., SPACCINI R., PALESE A.M., PICCOLO A., CELANO G., ZACCARDELL M. Onfarm compost: a useful tool to improve soil quality under intensive farming systems. Appl. Soil Ecol. 107, 13, 2016.

24. PANE C., CELANO G., PICCOLO A., VILLECCO D., SPACCINI R., PALESE A.M., ZACCARDELLI M. Effects of on-farm composted tomato residues on soil biological activity and yields in a tomato cropping system. Chem. Biol. Technol. Agric. 2, 1, 2015.

25. POLL CH., MARHAN S., INGWERSEN J., KANDELER E. Dynamics of litter carbon turnover and microbial abundance in a rye detritusphere. Soil Biol. Biochem. 40, 1306, 2008.

26. LUPWAYI N.Z., SOON Y.K. Soil microbial properties during decomposition of pulse crop and legume green manure residues in three consecutive subsequent crops. Can. J. Soil Sci. 96, 413, 2016.

27. YANG W., GUA Y., WANG X., CHEN CH., HU Y., CHENG L., GU S., XU X. Temporal variations of soil microbial community under compost addition in black soil of Northeast China. Appl. Soil Ecol. 121, 214, 2017.
28. PASCAULT N., CECILLON L., MATHIEU O., HENAULT C., SARR A., LEVEQUE J., FARCY P., RANJARD L., MARON P. In situ dynamics of microbial communities during decomposition of wheat, rape and alfalfa residues. Soil Ecol. 60, 816, 2010.

29. OPHEUSDEN A.H.M., BURGT G.J.H.M., RIETBERG P.I. Decomposition rate of organic fertilizers: effect on yield, nitrogen availability and nitrogen stock in the soil. Avalaible at: www.louisbolk.org/downloads/2666.pdf; accessed 18/3/2018 2012.

30. ELFSTRAND S., BÅTH B., MÅRTENSSON A. Influence of various forms of green manure amendment on soil microbial community composition, enzyme activity and nutrient levels in leek. Appl. Soil Ecol. 36, 70, 2007.

31. CHEN R., SENBAYRAM M., BLAGODATSKY S., MYACHINA O., DITTERT K., LIN X., BLAGODATSKAYA E., KUZYAKOV Y. Soil C and N availability determine the priming effect: microbial $\mathrm{N}$ mining and stoichiometric decomposition theories. Glob. Chang. Biol. 20, 56, 2014.

32. COOKE R.C., RAYNER A.D.M. Ecology of Saprophytic Fungi. Longman Group Limited, London, UK. 1984.

33. TELEKY B.-E., VODNAR D.C. Biomass-derived production of itaconic acid as a building block in specialty polymers. Review. Polymers 11: 1035 . 2019.

34. ZENG Z., GUO X., XU P., XIAO R., HUANG D., GONG X., CHENG M., YI H., ZENG G. Responses of microbial carbon metabolism and function diversity induced by complex fungal enzymes in lignocellulosic waste composting. Sci. Total Environ. 643, 539, 2018. 